\title{
Agenda setting analysis for maternal mortality reduction: exploring influential factors using Kingdon's Stream Model
}

Farah Babaey, ${ }^{1}$ Pouran Raessi ${ }^{1}$ and Hamid Ravaghi ${ }^{1,2}$

${ }^{1}$ School of Health Services, Management and Medical Information Science, Department of Health Services Management, Iran University of Medical Sciences, Tehran, Islamic Republic of Iran (Correspondence to: Hamid Ravaghi: ravaghih@gmail.com). ${ }^{2}$ World Health Organization Regional Office for the Eastern Mediterranean, Cairo, Egypt.

\begin{abstract}
Background: Maternal mortality is considered as unacceptable death.

Aims: This study aimed to analyse the agenda setting process for maternal mortality reduction policies in nine successful countries in achieving Millennium Development Goal 5 (MDG 5) using the Kingdon's multiple streams theory.

Methods: This comparative study analysed the agenda setting process in nine successful countries which achieved MDG 5. The agenda setting analysed the use of the Kingdon's multiple streams model. To extract similarities and differences in the agenda setting process, the content analysis method, available documents and reports, and the comparative table were used.

Results: The initial attention to the problem of high rate of maternal mortality was different in the studied countries, but MDGs and the countries' official reports were the main driver. Political stability, political will, key person's contribution and legislation were considered influential factors strengthening political stream. International technical or financial support, regional and international conferences, national plans and enabling factors, which provide technical feasibility, were the most important factors influencing the policy stream. Enabling factors included approving regulations and legislation, increased quantity and quality of human resources, organizational structure, service delivery enhancement, infrastructure development, providing medicines and equipment, and strengthening health information system.
\end{abstract}

Conclusions: The three streams: problem, policy and politics are not separate from each other. Political stability and commitment, having a national plan and benefiting from technical or financial support of international entities was a common feature among almost all the studied countries. The key actions leading to the opening of the window of opportunity were those actions that led to highlighting the problem.

Keywords: Maternal mortality, agenda setting, Kingdon's model, comparative study

Citation: Babaey F; Raessi P; Ravaghi H. Agenda setting analysis for maternal mortality reduction: exploring influential factors using Kingdon's Stream Model. East Mediterr Health J. 2019;25(3):160-171 https://doi.org/10.26719/emhj.18.025

Received: 04/12/17; accepted: 05/08/18

Copyright (C) World Health Organization (WHO) 2019. Some rights reserved. This work is available under the CC BY-NC-SA 3.o IGO license (https:// creativecommons.org/licenses/by-nc-sa/3.o/igo).

\section{Introduction}

Despite the advances made in reducing maternal mortality in recent decades, the elimination of avoidable deaths is considered as a vital concern and an agenda for policy makers (1). The analysis of related policies helps overcome existing defects and select appropriate solutions. In recent years, the use of policy-making models and frameworks in retrospective and prospective analyses of health policies and policy analyses in a systematic way have been published globally (2). One of the prestigious theories is the Kingdon's multiple streams theory. The Kingdon's model addresses how some issues are placed on the agenda (3).

Millennium Development Goals (MDGs) are eight common goals that were adopted in the United Nations by 189 countries in 2000 and should have been achieved by 2015 . The fifth goal is maternal health improvement. According to the report 2015, nine countries - Bhutan, Cabo Verde, Cambodia, East Timor, Islamic Republic of Iran, Lao People's Democratic Republic, Maldives, Mongolia and Rwanda were mentioned as successful countries in achieving MDG 5 of reducing maternal mortality rate (4). This analytical study aims to explore the process of agenda setting for the issue of reducing maternal mortality in these countries using the Kingdon's theory.

\section{Methods}

This descriptive-comparative study analyzed the development of agenda setting process of maternal mortality reduction based on the Kingdon's multiple streams model in nine successful countries. Required data that shape the problem, political and policy streams for maternal mortality in selected countries was gathered through reviewing national and international documents and reports published in valid scientific databases and electronic portals such as the World Health Organization (WHO) and upstream documents dated before 2015. Lack of documents about Cabo Verde was the main difficulty in gathering the information, especially since most of the documents were in either French or Spanish. The content analysis method and the comparative table were used to 
analyse the data.

The Kingdon's multiple streams theory emphasizes agenda setting and includes three independent streams that when joined together (Figure 1), they open a window of opportunity. The first stream, referred to as problem stream, is related to the problems, issues or challenges that have attracted the attention of society. The second stream, policy stream, addresses the policy options that researchers, stakeholders and executive bodies propose to solve the problem. Political transitions, specific national situations and social pressures all belongs to main elements of the third stream, i.e., the politics stream. At certain points, the streams come together and offer a window of opportunity for governments to decide how to address the issue at hand (3). Findings from each country were extracted and summarized using the comparative table. Then factors involved in the process of agenda setting were assessed using the content analysis method and the comparative table (Supplementary Tables 1-3).

\section{Results}

\section{Problem stream}

The findings of this study showed that international entities' advocacy drawing governments' attention to a specific issue has played an important role in highlighting the problem of maternal mortality in the process of agenda setting. In all selected countries, the problem has been highlighted since 1990. Several main factors led to reveal the problem; publishing the progress report of MDGs at country level highlighted the maternal mortality issue in these countries. A clear example can be observed in Bhutan (5), East Timor (6), Rwanda (7), Lao People's Democratic Republic (8), Maldives (9), Mongolia (10) and Cambodia (11). Also, conducting a national survey on maternal mortality and publishing the results in the Islamic Republic of Iran (12) and Cambodia (13) played an important role in highlighting the issue.

\section{Political stream}

The approach to shaping the political stream in the current study implied political stability, political will, key person's contribution and legislation. All the studied countries, were in a state of political stability and peace, in the process of agenda setting $(12,14-20)$ and enjoyed the commitment of statesmen in all of these countries $(5,10,12-15,21-25)$.

Key persons contributed in leading MDGs and in some cases specifically played a significant role in reducing maternal mortality, for example, the First Lady of Rwanda played a key role in leading policy-makers and planners to reduce maternal mortality through announcing the campaign of "Accelerating maternal mortality reduction" in 2009 and holding a meeting with high-level officials to this end (26). In addition, the Representative of the United Nations Population Fund in Bhutan played a special role in advocacy for reducing maternal mortality (14). Among the studied countries, two implemented interventions on legislation; in Mongolia the Public Health Policy was approved by its parliament in 2001 with the emphasis on access to reproductive health services for vulnerable groups and remote areas (27); and in Cambodia the Abortion Act was approved in its parliament in August 1997 (23).

\section{Policy stream}

The assessment of the policy stream in the agenda setting for maternal mortality reduction in this study included international technical or financial support, regional and international conferences, national plans and enabling factors which provide technical feasibility. All nine countries took advantage of technical or financial support from international organizations in the process of agenda setting $(6,13,14,18,19,22,26,28)$. This study indicates that the concerns for maternal mortality were communicated to officials via international and regional conferences.

For example, officials from the Lao People's Democratic Republic participated at the International Conference on Population and Development in Cairo (19); officials from Cambodia participated at the Safe Motherhood Conference in Kenya (13); officials from Rwanda participated at the 4th Africa Ministerial Conference in Addis Ababa (26); the East Timorese independence leader, who later became the first president, participated at the General Assembly for Millennium Development Goals in September 2000; and officials

Figure 1 The Kingdon's multiple streams framework (3)

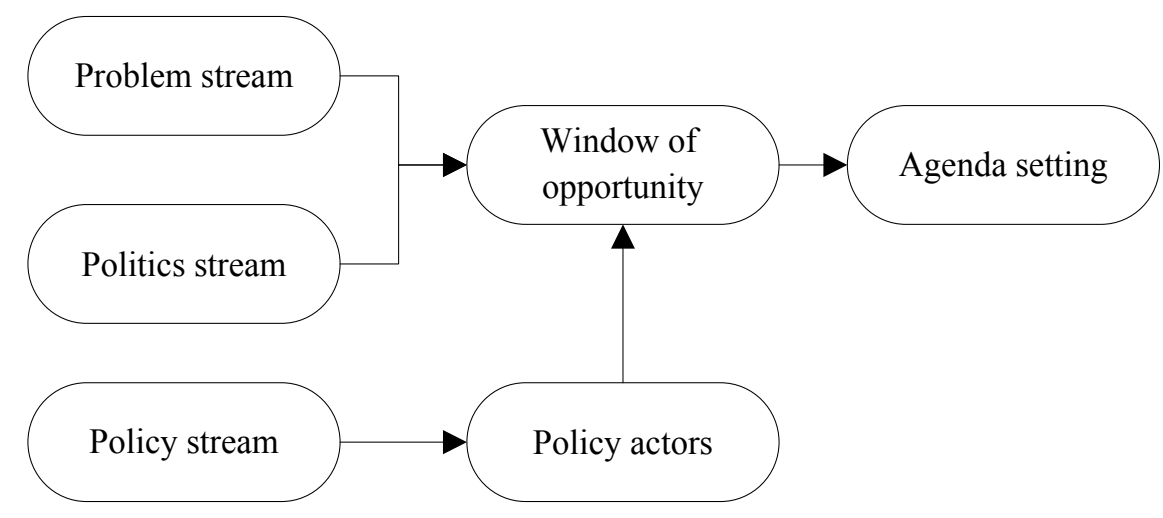


from East Timor participated in the Regional Conferences of the United Nations Development Fund on MDGs in Bangladesh in February 2003 (6). In addition, there was a well-defined plan in maternal mortality reduction in eight countries: Mongolia (22), Maldives (25), Lao People's Democratic Republic (19,24), Cambodia (13), Rwanda (26), Bhutan (5), Cab Verde (15), Islamic Republic of Iran (28).

In the current study, enabling factors that make technical feasibility and shape policy stream included organizational structure, human resources, services, medicine and medical equipment provision, and health information system. Three of the studied countries implemented interventions on organizational structure. For example, the Mother and Child Health Office was established in the Ministry of Health in the Islamic Republic of Iran (12); the National Mother and Child Commission was established in the Lao People's Democratic Republic (54); and a Mother and Child Unit was established within the Ministry of Health structure in East Timor (6).

Interventions to increase the number of human resources in the domain of mother and child health were implemented in six of the studied countries including Maldives (16), Rwanda (26), Islamic Republic of Iran (28), East Timor (6), Cambodia (25) and Mongolia (18); and interventions in empowering human resources were conducted in four countries: East Timor (6), Maldives (16), Islamic Republic of Iran (28) and Mongolia (18).
In all the studied countries, interventions have been implemented to improve service provision in maternal health $(5,6,8,15,16,18,22,23,28)$. Interventions have been also implemented to provide medicines and pharmaceutical products in Maldives (16), Lao People's Democratic Republic (19), Bhutan (5,29) and Mongolia (18); and interventions on health information systems implemented in Maldives (16) and Rwanda (26) by launching a maternal mortality audit system.

\section{Opening a window of opportunity}

Special events resulting in joining policy, politics and problem streams and opening a window of opportunity varied in the nine countries. In four countries, including Islamic republic of Iran (12), Bhutan (5), Cambodia (13) and Lao People's Democratic Republic (8), the window of opportunity opened after publishing the results of monitoring maternal mortality after considering MDGs. In two countries, Rwanda (22) and Cabo Verde (15), holding the advocacy campaign for maternal mortality reduction led to joining the three streams, and in Maldives (16) launching the maternal mortality audit was the joining point. In East Timor (20), holding a three-day training workshop aimed at raising public awareness for MDGs, situation analysis and assessment of relationship between goals of the national development plan with MDGs led to open the window of opportunity. In Mongolia, the development of maternal mortality reduction strategy was the opening of the window of opportunity (18) (Figure 2).

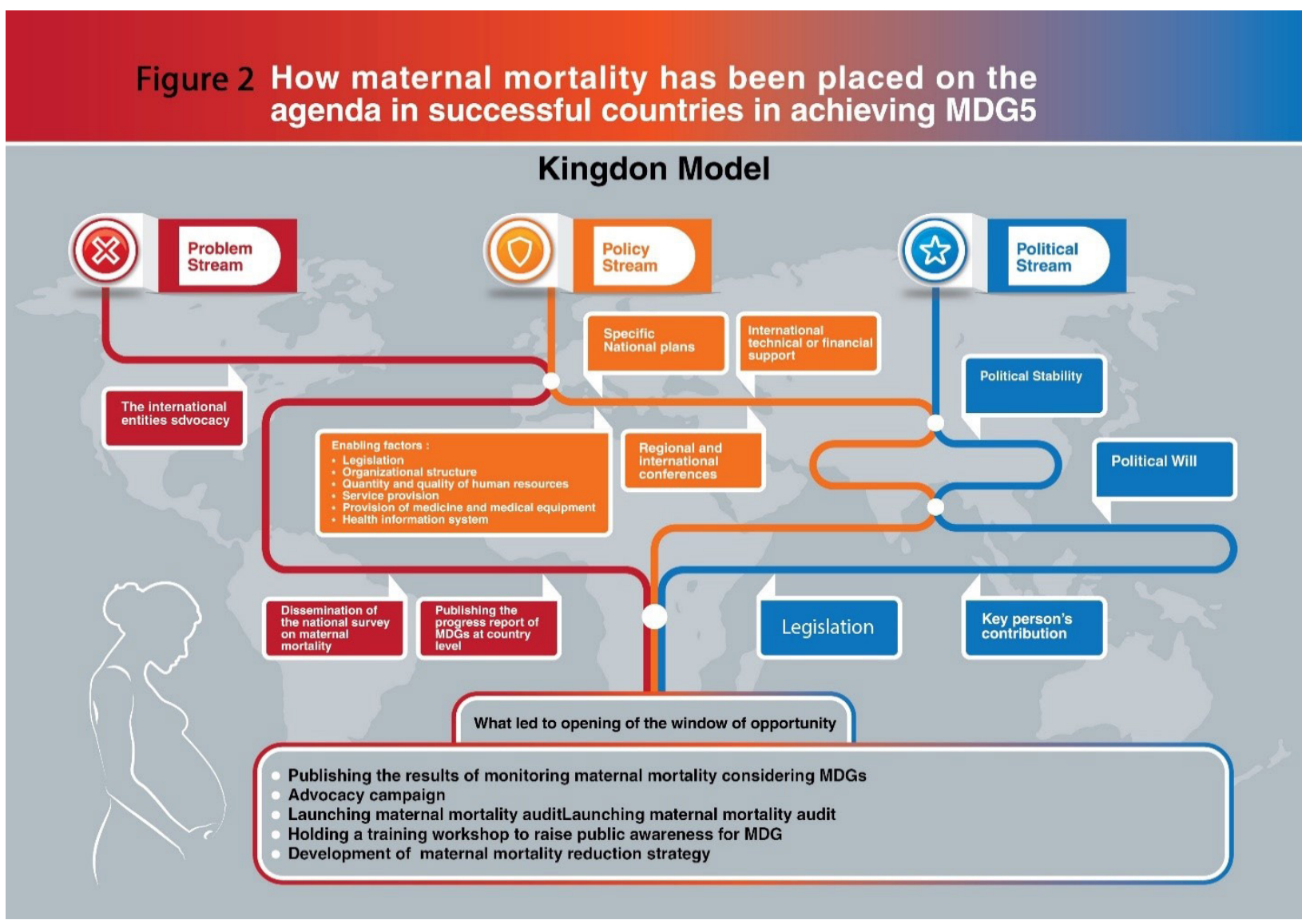




\section{Discussion}

Nine countries achieved the MDG 5 regarding maternal mortality reduction. Agenda setting of maternal mortality issue in these countries were analysed based on the three problem, policy and politics streams of Kingdon's model. Generation of evidence played a very important role in advocacy, planning and policy-making for maternal mortality reduction in low- and middle-income countries (30). This factor plays a significant role in highlighting the issue, convincing policy-makers and motivating elites (31).

\section{Problem stream}

In this study, using evidence to reveal the problem, convincing policy-makers and motivating elites have played a role in highlighting the problem. Thus, in six of the selected countries, the published progress report on the status of MDGs helped to shape the problem stream in the agenda setting process. In two countries, dissemination of the maternal mortality auditing report has also highlighted the problem. The assessment of the role of policy in achieving MDGs can be a guide to identify existing barriers and problems and facilitate the modification of current public policies to better achieve goals. The direct effects of the role of government in maternal and child mortality have been proved (32).

\section{Political stream}

In the current study, the approach to shaping the political stream implied political stability and political will to reduce maternal mortality in all nine countries. The political instability threatens maternal health by damaging health infrastructure and restricting transportation (33). In six of the studied countries, key persons contributed in leading MDGs, and in some cases specifically played a role in reducing maternal mortality. The support from country leaders and influential individuals, and its impact on agenda setting of issues related to maternal health, can be due to their influence (32). Policy-makers are more effective when they are led by leading people in the field of maternal mortality. Other countries' experience in this area confirmed this observation $(2,31)$.

The assessment of those countries having an accelerated trend in maternal mortality reduction revealed the importance of rules and legislation in the domain of mother and child health (34). In this study, two countries approved legislation related to maternal health.

\section{Policy stream}

Some studies mentioned the positive role of international financial aid in countries with accelerated trend of mother and child mortality reduction (31). All the studied countries took advantage of technical or financial support from international organizations, which might have facilitated agenda setting. A set of international conferences by the United Nations since 1990 also indicated the reaffirmation of global commitment to reduce maternal mortality (31). International innovative plans also created concerns regarding maternal mortality issue among many national health officials (35). In the current study, holding international and regional conferences in five countries and training workshops in two countries were among the influential factors.

It was noted that having a national plan specifying national priorities results in a targeted budget allocation, a shared common understanding of activities and a basis for accountability of community leaders and directors (36). Some of the successful countries included the achievement of the MDGs related to mother and child health in their priorities of national plans (30). This study finds that there was a well-defined plan in maternal mortality reduction in eight countries.

Although in some studies (30) having a specific structure within the governance domain was considered an effective success factor due to the creation of accountability, effectiveness and coordination, yet in the assessments no clear association was found between the existence of these structures and success in maternal mortality reduction. In two of the studied countries, an organizational structure responsible for addressing maternity health has been established.

Studies provide evidence of the direct and positive impact of the number of staff on health consequences (37). In many countries, mother and child mortality reduction resulted from the increase in key human resources' coverage in the domain of mother and child health (38). However, merely increasing the number of staff is not sufficient. Some studies indicated the importance of training, surveillance of staff and investment in improving the education system in the provision of midwifery emergency services (39). Interventions to increase the number of human resources were implemented in six of the studied countries and empowering human resources were conducted in four of these countries.

Strengthening the service delivery system to achieve MDGs is vital. These services include interventions that decrease mother and child mortality (30). In the current study, before opening the window of opportunity, all the countries implemented interventions in the domain of service delivery, primarily increasing access to and coverage of services and strengthening the technical feasibility of agenda setting.

A major part of mother and child mortality reduction was related to the improvement in access and receiving medicines and pharmaceutical products in the field of mother and child health and reproductive health. Four countries implemented interventions in providing medicines and pharmaceutical products. National efforts to reduce mother and child mortality depend on strengthening information systems and generating evidence for decision-making through assessment and evaluation mechanisms (30). A maternal mortality audit has been established in two of the countries.

Finally, it can be said that highlighting the issue (problem stream) had a significant impact on joining the three streams and opening the window of opportunity. The generation and use of evidence led to convincing 
policy-makers, motivating elites and drawing people's attention. However, effects of other streams on opening the window of opportunity cannot be ignored. The assessment of policies that led to success and stakeholder analysis was not intended in this study. Conducting qualitative research in each of these countries can provide more details in this regard. Also, the mentioned actions in each of these countries, in terms of time, took place before opening the window of opportunity. Comparison of the agenda setting process between the countries that achieved MDG 5 and the other countries would provide more evidence, but was not the focus of this study and could be addressed in future research.

\section{Conclusion}

The maternal mortality problem was placed on the agenda of policy-makers in the studied countries after international entities began agenda setting at the international level. This resulted in sensitization of officials and their commitment to reduce maternal mortality. Political stability and commitment, having a national plan, and benefiting from technical or financial support of international entities were common features among almost all the studied countries. Measures that strengthened health systems by providing health infrastructure, trained staff, information systems etc. create an enabling environment to address a problem and facilitate agenda setting.

An important reason for placing the issue of maternal health on the agenda of policy-makers is to highlight the issue by one of the three streams; strengthening one stream can strengthen others and all three should be strengthened together. The key actions leading to the open window of opportunity for maternal mortality reduction were those that led to highlighting the problem, generating evidence and its publication, and drawing the attention of policy-makers and planners. However, the impact of other streams cannot be ignored.

The model-based approach through the application of the Kingdon's model has been useful for the scrutiny of influential factors on agenda setting and this experience can be applied to the analysis of other policies. Analysing the experiences of the selected countries offers guidance on how political priorities can be generated for maternal mortality and other health problems.

Funding: Supported by Iran University of Medical Sciences (grant No: IUMS/SHMIS_1395/9221557203).

Competing interests: None declared.

\begin{tabular}{|c|c|c|c|c|c|c|c|c|}
\hline \multirow[b]{2}{*}{ Country } & \multicolumn{6}{|c|}{$\mathrm{MMR}^{*}$} & \multirow[b]{2}{*}{$\begin{array}{l}\text { \% change } \\
\text { in MMR } \\
\text { between } 1990 \\
\text { and } 2015\end{array}$} & \multirow[b]{2}{*}{$\begin{array}{c}\text { Average annual \% } \\
\text { change in MMR } \\
\text { between } 1990 \text { and } \\
2015\end{array}$} \\
\hline & 1990 & 1995 & $\begin{array}{r}M \\
2000\end{array}$ & $\begin{array}{l}R^{*} \\
2005\end{array}$ & 2010 & 2015 & & \\
\hline Iran (Islamic Republic of)(4) & 123 & 80 & 51 & 34 & 27 & 25 & 79.7 & 6.4 \\
\hline Bhutan(4) & 945 & 636 & 423 & 308 & 204 & 148 & 84.3 & 7.4 \\
\hline Cambodia(4) & 1020 & 730 & 484 & 315 & 202 & 161 & 84.2 & 7.4 \\
\hline Cabo Verde(4) & 256 & 150 & 83 & 54 & 51 & 42 & 83.6 & 7.2 \\
\hline Lao People's Democratic Republic(4) & 905 & 695 & 546 & 418 & 294 & 197 & 78.2 & 6.1 \\
\hline Maldives(4) & 677 & 340 & 163 & 101 & 87 & 68 & 90.0 & 9.2 \\
\hline Mongolia(4) & 186 & 205 & 161 & 95 & 63 & 44 & 76.3 & 5.8 \\
\hline Rwanda(4) & 1300 & 1260 & 1020 & 567 & 381 & 290 & 77.7 & 6.0 \\
\hline Timor-Leste(4) & 1080 & 897 & 694 & 506 & 317 & 215 & 80.1 & 6.5 \\
\hline
\end{tabular}

${ }^{*}$ Maternal deaths per 100 ooo live births (4) 


\section{Supplementary Table 2 The multiple streams of Kingdon's theory in terms of MDG 5 reduction in the nine studied countries}

\begin{tabular}{|c|c|c|c|}
\hline Country & Problem Stream & Policy Stream & Political Stream \\
\hline $\begin{array}{l}\text { Islamic } \\
\text { Republic } \\
\text { of Iran }\end{array}$ & $\begin{array}{l}\text { At the same time as } \\
\text { the establishment of } \\
\text { the country health } \\
\text { care network in } 1985 \text {, } \\
\text { maternal and child } \\
\text { health was set as } \\
\text { one of the important } \\
\text { components of the } \\
\text { health service delivery } \\
\text { system (12). }\end{array}$ & $\begin{array}{l}\text { - Emphasis on the reduction of maternal mortality in the third } \\
\text { to fifth country development plans } \\
\text { - Launch of the higher school of midwifery in } 1939 \\
\text { - Establishment of the mother and child health office affiliated } \\
\text { to the general office of family health at the ministry of health } \\
\text { in } 1976 \\
\text { - Launch of the healthcare network system in } 1985 \\
\text { - Training family health technician in } 1983 \text { to provide integrated } \\
\text { services } \\
\text { - Training local midwives in } 1983 \\
\text { - Training village midwife in } 1990 \\
\text { - Establishment of maternity facilities in villages along with } \\
\text { rural health centers to increase access (28). }\end{array}$ & $\begin{array}{l}\text { - Government commitment to } \\
\text { promoting maternal health } \\
\text { - Government commitment to the } \\
\text { Millennium Development Goals } \\
\text { - Publishing results of the RAMOS } \\
\text { study in } 2008 \text { (12). }\end{array}$ \\
\hline Bhutan & $\begin{array}{l}\text { Since 1990, maternal } \\
\text { mortality has been } \\
\text { recognized as a problem } \\
\text { ( } 560 \text { per 100,000 in } \\
\text { 1990). } \\
\text { In 2002, the trend } \\
\text { assessment of the } \\
\text { achievement of the } \\
\text { MDGs was conducted } \\
\text { and its results } \\
\text { were published in } \\
\text { which challenges } \\
\text { ahead to reduce } \\
\text { maternal mortality } \\
\text { and the necessity } \\
\text { of strengthening } \\
\text { infrastructures were } \\
\text { emphasized }(5,29)\end{array}$ & $\begin{array}{l}\text { - The role of the representative of the United Nations } \\
\text { Population Fund, who has played a special role in advocacy } \\
\text { - Technical support of WHO for developing national plans } \\
\text { - Development of a maternal and child health programme } \\
\text { within the National Action Plan } 1997 \\
\text { The following actions were taken to achieve the goal of this } \\
\text { Action Plan : } \\
\text { - Tetanus oxidation } \\
\text { - Distribution of folic acid and iron to reduce anaemia in } \\
\text { pregnant women } \\
\text { - Implementation of the Safe Motherhood and Maternal health } \\
\text { programme, focusing on the provision of "Women-Friendly } \\
\text { Services" in 1997 with the following objectives: } \\
\text { - Enhancement of pre and postnatal care } \\
\text { - Increase the skilled birth attendance percentage } \\
\text { - Distribution of safe delivery kits at home since } 1998 \\
\text { - Establishment of midwifery care centers for maternal } \\
\text { emergencies (Emoc) since } 2000 \text { (14,29) } \\
\text { - Development of a partnership document with WHO in early } \\
\text { - } 2000 \\
\text { Development of a strategy for cooperation with WHO (2001- } \\
\text { 2002) } \\
\text { - Publishing the first official report on the progress of the } \\
\text { MDGs in Bhutan in } 2002 \\
\text { The ninth country five-year Plan (2002-2007) has focused on } \\
\text { maternal health, in particular reducing maternal mortality, } \\
\text { increasing the percentage of skilled birth attendance and } \\
\text { reducing anaemia as a facilitator of maternal mortality } \\
\text { reduction (29). }\end{array}$ & $\begin{array}{l}\text { - The king's commitment to } \\
\text { maternal health } \\
\text { - The queen's commitment to } \\
\text { maternal health } \\
\text { - The government's commitment } \\
\text { to achieve the MDGs (5) }\end{array}$ \\
\hline East Timor & $\begin{array}{l}\text { Since 2001, with } \\
\text { publication of the } \\
\text { first progress report } \\
\text { on MDGs, maternal } \\
\text { mortality has been } \\
\text { considered a problem. } \\
\text { In the first national } \\
\text { development plan } 2002 \text {, } \\
\text { which was developed in } \\
\text { compliance with MDGs, } \\
\text { maternal mortality was } \\
\text { mentioned as one of the } \\
\text { major problems of the } \\
\text { country }(20,21) \text {. }\end{array}$ & $\begin{array}{l}\text { From September } 1999 \text { to January } 2000, \text { WHO, together with } \\
\text { UNICEF, acted as a "Temporary Ministry of Health". } \\
\text { An Interim Health Authority was formed in February 2000, } \\
\text { followed by the creation of the Division of Health Services in } \\
\text { July } 2000 \text {. The Ministry of Health came into being in September } \\
\text { 2001. (the reduction of maternal and infant mortality was one of } \\
\text { the mentioned goals) (20), and conducted the following: } \\
\text { - Establishment of the maternal and neonatal health unit in } \\
\text { the structure of the ministry of health as a subset of the } \\
\text { healthcare services delivery sector } \\
\text { - Training midwives on safe motherhood, safe childbirth, and } \\
\text { management of sexually transmitted infections (STIs) in } 2000 \\
\text { by three international agencies including UNFPA, WHO, } \\
\text { UNICEF } \\
\text { - Employment of gynecologists and obstetricians by the } \\
\text { United Nations Population Fund for the access to services in } \\
\text { gynecological and obstetric emergencies } \\
\text { - Publishing the first official progress report on MDGs in } 2001 \\
\text { (6) } \\
\text { - situation analysis report of the country, titled country general } \\
\text { assessment with the participation of the International Agency } \\
\text { in } 2001 \\
\text { - Participation of the country's delegate in regional conferences } \\
\text { on MDGs - United Nations Development Fund Conference in } \\
\text { Bangladesh in February } 2003 \\
\text { - A joint training workshop by the United Nations Development } \\
\text { Fund and the World Bank in Fiji in March } 2003\end{array}$ & $\begin{array}{l}\text { - Change in the type of governance } \\
\text { and political stability } \\
\text { - The country, after centuries of } \\
\text { being a colony, in } 2002 \text { gained } \\
\text { independence and left behind the } \\
\text { internal conflicts and political } \\
\text { instability. } \\
\text { Statesmen's commitment to achieve } \\
\text { the MDGs: } \\
\text { - Participation of the East Timorese } \\
\text { independence leader, who later } \\
\text { became the first president, } \\
\text { at the General Assembly for } \\
\text { the development of MDGs in } \\
\text { September } 2000 \\
\text { - Participation of the prime } \\
\text { minister, key ministers and } \\
\text { representatives of the private } \\
\text { sector in the committee on the } \\
\text { management of MDGs (6) }\end{array}$ \\
\hline
\end{tabular}




\begin{tabular}{|c|c|c|c|}
\hline Country & Problem Stream & Policy Stream & Political Stream \\
\hline Rwanda & $\begin{array}{l}\text { After decades of tension } \\
\text { and genocide, Rwanda } \\
\text { faced many health } \\
\text { problems. Severe labour } \\
\text { shortage, constraints on } \\
\text { health infrastructure, } \\
\text { and high rates of } \\
\text { maternal and infant } \\
\text { mortality (26). }\end{array}$ & $\begin{array}{l}\text { - Community-based measures to reduce maternal mortality in } \\
\text { 1995; launch and employment of community health workers } \\
\text { Publishing the national report on the progress of the MDGs } \\
\text { in Rwanda by the government with the participation of UNDP } \\
\text { ( } 2003,2007) \\
\text { - Modification of the system of apprenticeship of the } \\
\text { community health workers; for each village, three persons } \\
\text { one man and one woman for health care and one woman } \\
\text { particularly for maternity care during pregnancy and pre, } \\
\text { post-natal and neonatal care (2007) } \\
\text { - Launch of maternal mortality audit in } 2008 \\
\text { - Development of a roadmap to accelerate the reduction of } \\
\text { maternal mortality with the participation of the United } \\
\text { Nations Population Fund in } 2008 \\
\text { - Changing the procedure of childbirth at home to childbirth at } \\
\text { maternity centres } \\
\text { - Decentralization of health services } \\
\text { - Use of community participation }(22,26)\end{array}$ & $\begin{array}{l}\text { After decades of tension and } \\
\text { genocide in 1994, which resulted in } \\
\text { more than two million homeless } \\
\text { people, Rwanda has been politically } \\
\text { stable for almost two decades. } \\
\text { - The commitment of the president } \\
\text { and the first lady to maternal } \\
\text { health } \\
\text { - The commitment of government } \\
\text { to achieve the MDGs } \\
\text { - Participation of the health } \\
\text { minister in the } 4 \text { th Africa } \\
\text { Ministerial Conference, held in } \\
\text { May 20o9, Addis Ababa } \\
\text { - Launching a campaign to reduce } \\
\text { maternal mortality in Africa with } \\
\text { the motto "Women should not } \\
\text { lose their lives when they save } \\
\text { lives" } \\
\text { - Announcement of this campaign } \\
\text { in Rwanda on } 7 \text { October, } 2009 \text { by } \\
\text { the first lady of the country }(22,26)\end{array}$ \\
\hline Cabo Verde & $\begin{array}{l}\text { Maternal mortality } \\
\text { was recognized as an } \\
\text { issue in the } 1990 \text { s and } \\
\text { was put in the 2001- } \\
2005 \text { programme as a } \\
\text { priority. } \\
\text { Maternal mortality } \\
\text { reduction was targeted } \\
\text { in the national plan } \\
2000 \text { (15) }\end{array}$ & $\begin{array}{l}\text { - Support of the UN representative in the country } \\
\text { - Developing the national strategy 2002-2005 for achieving the } \\
\text { MDGs } \\
\text { - Support of international organizations } \\
\text { - Organizing the NGOs as part of the health system to offer } \\
\text { clinical and counseling services for pregnancy and birth } \\
\text { - Developing a national plan to integrate reproductive health } \\
\text { and maternal mortality in the health system 20o1. } \\
\text { - A reproduction health programme has been designed as well } \\
\text { as standards and procedures of services (15). }\end{array}$ & $\begin{array}{l}\text { - After independence from Portugal } \\
\text { in 1975, the political situation } \\
\text { became meaningful and the } \\
\text { power between various political } \\
\text { groups was rotated and stabilized. } \\
\text { - The prime minister's } \\
\text { commitment to maternal health } \\
\text { - Commitment of the minister of } \\
\text { economy to achieve the MDGs } \\
\text { - Commitment of the government } \\
\text { of Cabo Verde to include } \\
\text { Maternal health in the health } \\
\text { system (15) }\end{array}$ \\
\hline
\end{tabular}




\begin{tabular}{|c|c|c|c|}
\hline Country & Problem Stream & Policy Stream & Political Stream \\
\hline Cambodia & $\begin{array}{l}\text { Maternal mortality } \\
\text { has been mentioned } \\
\text { as a major issue in the } \\
\text { health system in the } \\
\text { safe motherhood plan } \\
\text { in } 1997(11,13)\end{array}$ & 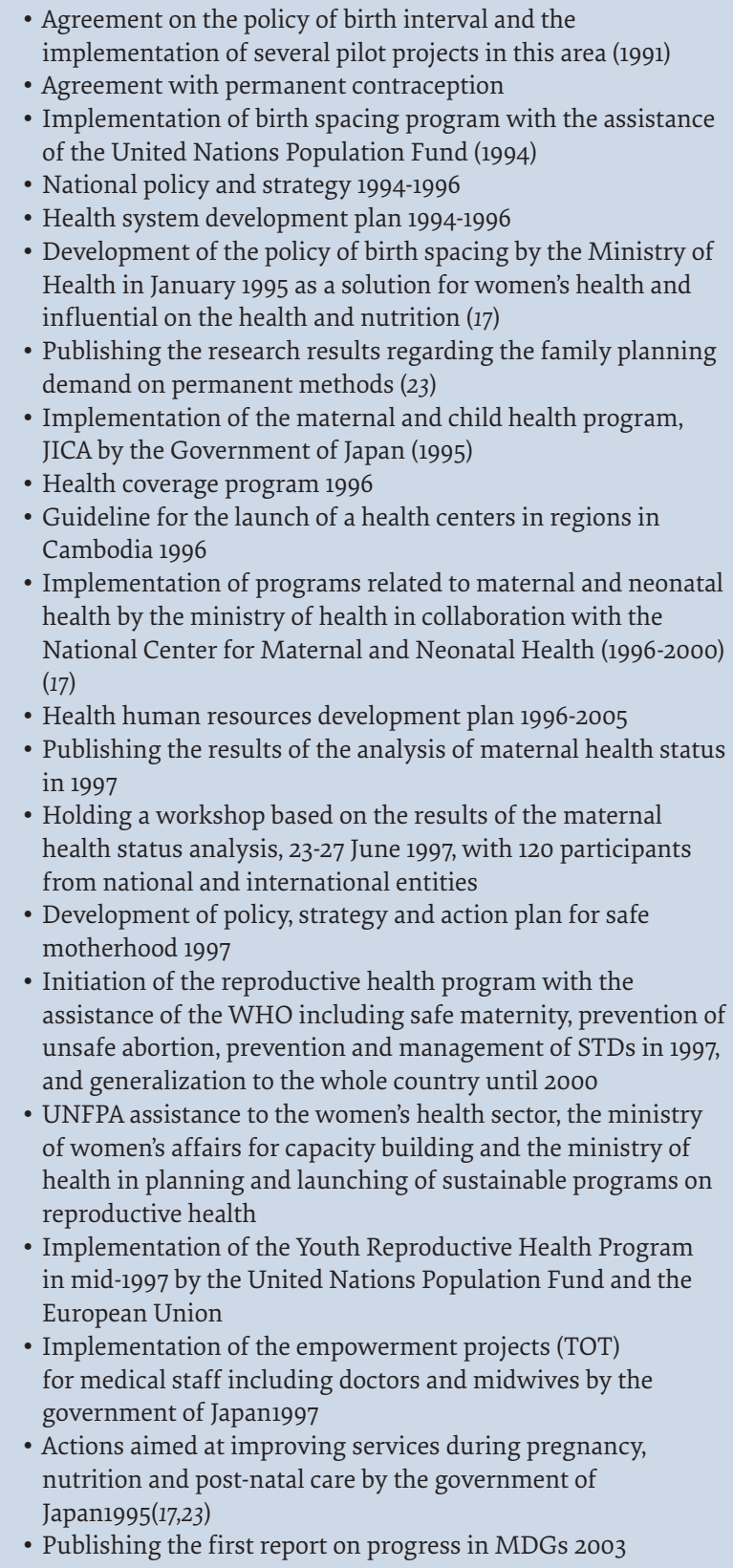 & $\begin{array}{l}\text { - After two decades of war and } \\
\text { political instability, since the } \\
1998 \text { election a kind of political } \\
\text { stability was gained that allows } \\
\text { the continuity of policy making } \\
\text { and planning. Political stability } \\
\text { (23) } \\
\text { - The prime minister's } \\
\text { commitment to maternal health } \\
\text { - The commitment of the } \\
\text { government and the minister of } \\
\text { health to achieve the MDGs } \\
\text { - Endorsement of the } \\
\text { recommendations of the Safe } \\
\text { Motherhood Conference, } \\
\text { Nairobi, Kenya, } 1987 \text { and the } \\
\text { Action Plan of the International } \\
\text { Conference on Population and } \\
\text { Development, Cairo, Egypt, 1994 } \\
\text { by the delegation of the Royal } \\
\text { Government of Cambodia. } \\
\text { - Approval of the Abortion Act in } \\
\text { parliament in August } 1997 \text { (13,17) }\end{array}$ \\
\hline $\begin{array}{l}\text { Lao People's } \\
\text { Democratic } \\
\text { Republic }\end{array}$ & $\begin{array}{l}\text { In 1995, the high } \\
\text { maternal mortality } \\
\text { rate was highlighted } \\
\text { in the national birth } \\
\text { spacing policy and } \\
\text { with understanding } \\
\text { the importance of the } \\
\text { issue, this policy was } \\
\text { developed in order } \\
\text { to reduce maternal } \\
\text { mortality and } \\
\text { morbidity }(8,19) \text {. }\end{array}$ & $\begin{array}{l}\text { Participation of the delegation of the country in the Cairo } \\
\text { International Conference on Population and Development } \\
\text { - Development of national birth spacing policy in } 1995 \\
\text { - Development of the safe motherhood and safe childbirth } \\
\text { program in } 1997 \\
\text { - Development of national population and development policy } \\
\text { in } 1999 \text { (19) } \\
\text { - Tetanus vaccination } \\
\text { - Prescribing folic acid and iron to prevent anemia during } \\
\text { pregnancy } \\
\text { - National report on the progress status of MDGs by the } \\
\text { government with the participation of UNDP in } 2004(8)\end{array}$ & $\begin{array}{l}\text { - The commitment of the ministry } \\
\text { of health to the national maternal, } \\
\text { infant and child health programs } \\
\text { - government commitment to } \\
\text { achieve the MDGS (19) } \\
\text { - the role of the deputy of the } \\
\text { prime minister, who also was the } \\
\text { minister of foreign affairs, as the } \\
\text { head of the national committee } \\
\text { for monitoring the achievement } \\
\text { to MDGs } \\
\text { - Establishment of the national } \\
\text { commission of mother and child } \\
\text { (1999) (8) }\end{array}$ \\
\hline
\end{tabular}




\begin{tabular}{|c|c|c|c|}
\hline Country & Problem Stream & Policy Stream & Political Stream \\
\hline Maldives & $\begin{array}{l}\text { With the } \\
\text { Introduction of a } \\
\text { maternal death audit in } \\
\text { 1997, more reliable data } \\
\text { on MMR was available. } \\
\text { In } 1990 \text { the maternal } \\
\text { mortality rate stood at } \\
\text { around } 500 \text { per 100,000 } \\
\text { live births and was } \\
\text { addressed as a health } \\
\text { problem (16). }\end{array}$ & $\begin{array}{l}\text { Development of the first three-year health programme focusing } \\
\text { on primary healthcare services } 1980 \text { (following the declaration of } \\
\text { Alma-Ata in 1997) } \\
\text { - Maternal mortality assessment system since } 1990 \\
\text { - Increase the number of human resources in health system to } \\
56 \%(1994-1999)(16) \\
\text { - Development of the first long-term health plan (1996-2005) in } \\
1995 \\
\text { - Development of the second long-term health plan (2006-2015) } \\
\text { - Detection of high-risk pregnancies } \\
\text { - Improving the quality of services in distant areas } \\
\text { - Focusing on reduction of anaemia in pregnant women } \\
\text { (distribution of supplements) } \\
\text { - Development of hospitals } \\
\text { - Employment of doctors in health centres } \\
\text { - Sducation for health system human resources } \\
\text { on remote islands } \\
\text { - Change the service centres on remote islands to hospitals }(9) \\
\text { - Publishing the progress report on MDGS by the Ministry of } \\
\text { Health and Ministry of Planning } 2005,2007\end{array}$ & $\begin{array}{l}\text { - Government commitment to } \\
\text { fulfill international goals (25) }\end{array}$ \\
\hline Mongolia & $\begin{array}{l}\text { The country entered } \\
\text { into a democratic phase } \\
\text { in } 1990 \text { after the Soviet } \\
\text { Union's collapse. The } \\
\text { years immediately } \\
\text { following the political } \\
\text { transition witnessed } \\
\text { a deterioration of the } \\
\text { healthcare system } \\
\text { and a resultant rise in } \\
\text { maternal mortality. } \\
\text { The high rate of } \\
\text { maternal mortality has } \\
\text { been recognized since } \\
1990 \text { (18) }\end{array}$ & $\begin{array}{l}\text { - Collaborative strategic approach for reducing maternal } \\
\text { mortality } \\
\text { - Maternal mortality reduction strategy 2001-2004 } \\
\text { - National strategic plan for reproductive health } \\
\text { - Support from national and international partners (10) } \\
\text { - Training of staff about reproductive and sexual health } \\
\text { (including gynecologists) with the assistance of the United } \\
\text { Nations Population Fund and UNICEF } \\
\text { - Providing required medicines in midwifery emergencies } \\
\text { - United Nations Population Fund support for contraceptive } \\
\text { distribution } \\
\text { - Conducting training and campaigns for family planning } \\
\text { training that had impact on the acceptance and demand for } \\
\text { reproductive health services. } \\
\text { - Reestablishment of maternal waiting homes near the hospital } \\
\text { in } 1993 \text { (as an important part of the referral system) } \\
\text { - Focusing on intrapartum care } \\
\text { - Opening of local diagnostic and therapeutic centres in three } \\
\text { regions of the country } \\
\text { - Logistic services of the United Nations Population Fund for } \\
\text { reproductive health programmes (27) }\end{array}$ & $\begin{array}{l}\text { - Government commitment to } \\
\text { fulfill international obligations } \\
\text { - Legal abortion act } 1989 \\
\text { - The adoption of the public health } \\
\text { policy in } 2001 \text { by the parliament } \\
\text { with the emphasis on the } \\
\text { improved access to reproductive } \\
\text { health services for vulnerable } \\
\text { groups and remote areas (18) }\end{array}$ \\
\hline
\end{tabular}




\begin{tabular}{|c|c|}
\hline Country & Window of opportunity \\
\hline $\begin{array}{l}\text { Islamic Republic } \\
\text { of Iran }\end{array}$ & $\begin{array}{l}\text { Although the maternal mortality issue has been considered since 1985, after publishing the results of RAMOS study in } 1997 \text {, } \\
\text { the maternal mortality issue was put at the centre of attention (12). }\end{array}$ \\
\hline Bhutan & $\begin{array}{l}\text { The maternal mortality issue has been considered as a problem since 1990; however, the issue attracted attention through } \\
\text { developing the mother and child health improvement programme and the safe motherhood and reproductive health } \\
\text { programme in 1997, and after publishing the first progress report on MDGs in } 2002 \text { it was put at the centre of attention (14). }\end{array}$ \\
\hline East Timor & $\begin{array}{l}\text { Maternal mortality reduction was considered an issue since } 2001 \text { along with publishing the first progress report on MDGs. } \\
\text { However, after holding a two-day training workshop in March 2003, it was put at the centre of attention. This workshop } \\
\text { was held aiming at raising public awareness about MDGs, the current situation analysis and the assessment of relationship } \\
\text { between goals of the national development plan with MDGs and challenges ahead to achieve the MDGs (6). }\end{array}$ \\
\hline Rwanda & $\begin{array}{l}\text { Although the agenda setting process had been started in } 2000 \text {, the issue was put at the centre of attention through } \\
\text { announcing the campaign of "accelerating maternal mortality reduction in Africa" in Rwanda on } 7 \text { October } 2009 \text { by the first } \\
\text { lady of the country and holding a meeting with high levels officials ( } 26) \text {. }\end{array}$ \\
\hline Cabo Verde & $\begin{array}{l}\text { Although the agenda setting process had been started in } 2000 \text {, the issue of maternal mortality was put at the centre of } \\
\text { attention through launching the national campaign to achieve MDGs in } 2003(15) \text {. }\end{array}$ \\
\hline Cambodia & $\begin{array}{l}\text { The agenda setting process had been started in } 1990 \text { and the issue was put at the centre of attention after publishing results } \\
\text { of the analysis of maternal health status in } 1997(13) \text {. }\end{array}$ \\
\hline $\begin{array}{l}\text { Lao People's } \\
\text { Democratic } \\
\text { Republic }\end{array}$ & $\begin{array}{l}\text { While the problem stream had been considered since } 1995 \text { and various programmes were developed to reduce maternal } \\
\text { mortality from } 1995 \text { to } 2004 \text {, it seems that the window of opportunity for maternal mortality reduction opened after the } \\
\text { development of the comprehensive reproductive health plan in } 2004 \text { and publishing the national progress report on MDGs } \\
\text { (19). }\end{array}$ \\
\hline Maldives & $\begin{array}{l}\text { The agenda setting process started in } 1990 \text {. In } 1997 \text {, the window of opportunity for maternal mortality reduction was opened } \\
\text { along with launching maternal mortality audit and consequently several actions were taken to reduce maternal mortality. } \\
\text { Again, in 2009, when maternal mortality rate increased, a new window of opportunity was opened that led to revising the } \\
\text { maternal mortality assessment system and establishing a special committee to assess mortality and morbidity. Special } \\
\text { attention was paid to the issue of maternal mortality and a series of new actions were shaped (g). }\end{array}$ \\
\hline Mongolia & $\begin{array}{l}\text { It seems that the agenda setting process started in } 1990 \text { and through developing the maternal mortality reduction strategy } \\
\text { (2001-2004), the maternal mortality issue was put at the centre of attention (27). }\end{array}$ \\
\hline
\end{tabular}

\section{Analyse de la définition des enjeux prioritaires pour la réduction de la mortalité maternelle : exploration des facteurs influents à l'aide du modèle des flux de Kingdon}

\section{Résumé}

Contexte : La mortalité maternelle est considérée comme inacceptable.

Objectifs : La présente étude visait à analyser le processus de définition des enjeux prioritaires dans les politiques de réduction de la mortalité maternelle dans neuf pays qui ont réussi à réaliser le cinquième objectif du Millénaire pour le développement (OMD 5) en utilisant la théorie des flux multiples de Kingdon.

Méthodes : Cette étude comparative a analysé le processus de définition des enjeux prioritaires dans neuf pays qui ont réussi à réaliser l'OMD 5. Ce processus a permis d'analyser l'utilisation du modèle à flux multiples de Kingdon. Afin d'extraire les similitudes et les différences dans la définition des enjeux prioritaires, la méthode d'analyse du contenu, les documents et les rapports disponibles, ainsi qu'un tableau comparatif ont été utilisés.

Résultats : L'attention initiale accordée au problème du taux élevé de mortalité maternelle était différente dans les pays étudiés, mais les OMD et les rapports officiels des pays en étaient le principal moteur. La stabilité et la volonté politique, la contribution des personnes clés et la législation ont été considérées comme des facteurs influents qui renforcent le courant politique. L'appui technique ou financier international, les conférences régionales et internationales, les plans nationaux et les facteurs favorables, qui assurent la faisabilité technique, étaient les facteurs les plus importants qui influencent le courant politique. Les facteurs habilitants comprenaient l'approbation des règlements et des lois, l'augmentation de la quantité et de la qualité des ressources humaines, la structure organisationnelle, l'amélioration de la prestation des services, le développement des infrastructures, la fourniture de médicaments et de matériel et le renforcement du système d'information sanitaire.

Conclusions : Les trois flux du modèle - problème, stratégie et politique - ne sont pas séparés les uns des autres. La stabilité et l'engagement politiques, le fait d'avoir un plan national et de bénéficier de l'appui technique ou financier d'entités internationales sont des caractéristiques communes à presque tous les pays étudiés. Les mesures clés qui ont conduit à l'ouverture de la fenêtre d'opportunité sont celles qui ont permis de mettre le problème en évidence. 


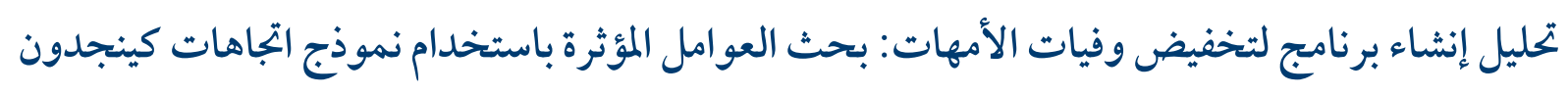

$$
\text { الخلاح بابابي، بوران رئيسي، حميد رواقي }
$$

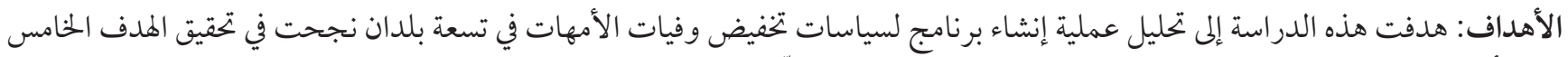

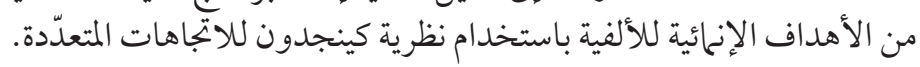

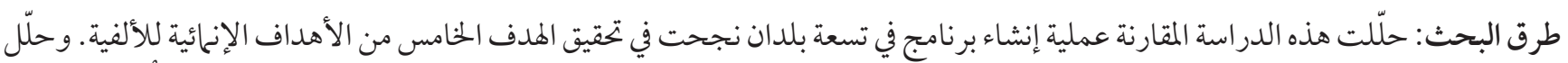

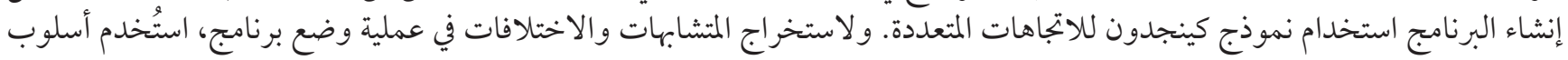

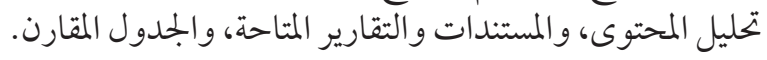

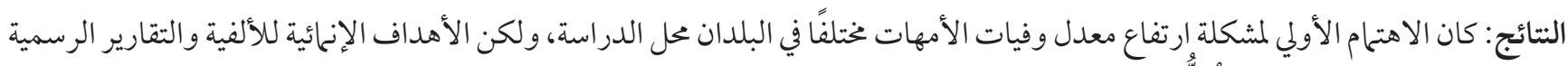

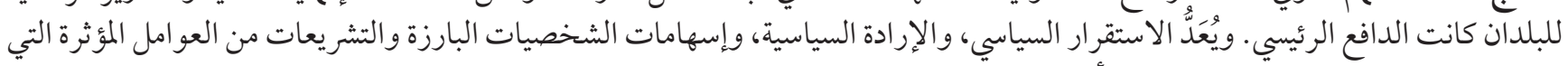

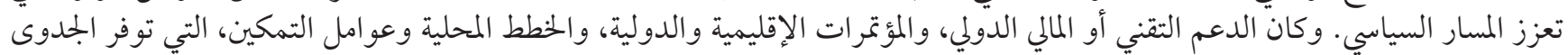

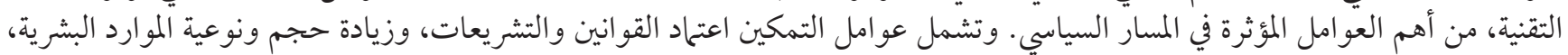

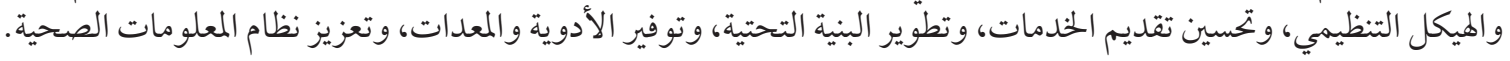

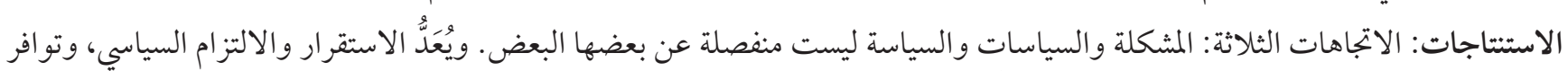

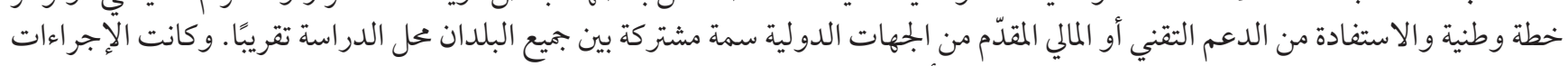

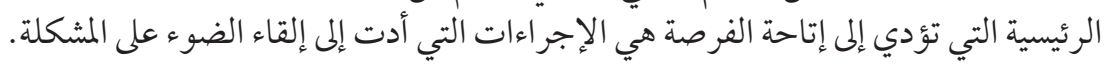

\section{References}

1. Bauserman M, Lokangaka A, Thorsten V, Tshefu A, Goudar SS, Esamai F, et al. Risk factors for maternal death and trends in maternal mortality in low- and middle-income countries: a prospective longitudinal cohort analysis. Reprod Health. 2015; 8(12):1742-4755.

2. Ha BTT, Mirzoev T, Mukhopadhyay M. Shaping the health policy agenda: the case of safe motherhood policy in Vietnam. Int J Health Policy Manag. 2015; 4(11):741-6. http://dx.doi.org/10.15171/ijhpm.2015.153

3. Walt G, Gilson L. Can frameworks inform knowledge about health policy processes? Reviewing health policy papers on agenda setting and testing them against a specific priority-setting framework. Health policy and planning. 2014; 29(suppl_3):iii6-iii22.

4. World Health Organization. Trends in maternal mortality: 1990-2015: estimates from WHO, UNICEF, UNFPA. Geneva, Switzerland: World Bank Group and the United Nations Population Division; 2015.

5. UNDP. Millennium Development Goals. Progress Report. Thimpu; 2002.

6. World Health Organization. Timor-Leste Millennium Development Goals Report. Timor-Leste; Geneva: World Health Organization; 2004.

7. Ministry Of Health. Human Resources for Health Strategic Plan 2011-2016. Republic of Rwanda; 2011.

8. WHO. The Millennium Development Goals Progress Report 2015 (Lao) 2015 [cited 2017 June 19]. (http://www.wpro.who.int/laos/ publications/20161017-mdg-report-moh-lao/en/).

9. Ministry of Health Republic of Maldives. Maldives Health Profile; 2016.

10. World Health Organization. WHO country cooperation strategy for Mongolia 2010-2015. Manila: WHO Regional Office for the Western Pacific; 2009.

11. World Health Organization. Cambodia-WHO country cooperation strategy: 2016-2020. World Health Organization. Manila: Regional Office for the Western Pacific; 2016.

12. Ministry of Health and Medical Education. National Maternal Mortality Surveillance System. Isfahan University of Medical Sciences; 2016.

13. Ministry of Health. Safe Motherhood National Policy and Strategies. Cambodia: National Maternal and Child Health Centre; 1997.

14. Planning Commission Royal Government of Bhutan. Bhutan Millennium Development Goals Needs Assessment and Costing Report (2006-2015). Thimphu: Bhutan Times Ltd; 2007.

15. Objectivos do milénio para o desenvolvimento, uma avaliação dos esforcos realizados. Cabo

16. Ministry of Health. The Maldives Health Report 2004. Republic of Maldives: Health Information and Research Unit; 2004.

17. Ministry of Health. Reproductive Health in Cambodia: A Summary of Research Findings 1990-1998. Kingdom of Cambodia; 1998. 
18. Government of Mongolia (GOM). Millennium Development Goals: National Report on the Status of Implementation in Mongolia. Ulaanbaatar, Mongolia; 2004.

19. United Nations. Millennium Development Goals Progress Report Lao PDR. Government of Lao PDR; 2004.

20. March C. Health Profile, Democratic Republic of Timor-Leste 2002 [cited 2017 June 18]. (http://www.searo.who.int/timorleste/ publications/country_profile/en/).

21. Snell B, Martins N, Malau C, Belo OMF, Gomes L, Vital M, et al. Strengthening health systems in Timor-Leste. Dev Bull (Canberra). 2005; 68:95-8.

22. World Health Organization. Success factors for women's and children's health Rwanda. Geneva: World Health Organization; 2015 .

23. World Health Organization. Success factors for women's and children's health Cambodia. Geneva, World Health Organization; 2015.

24. United Nations. The Millennium Development Goals Report, Progress and transition of Health-related MDGs to SDGs in Lao PDR. Lao PDR; 2015.

25. Ministry of Health. Health Master Plan 2006 - 2015. Republic of Maldives; 2006.

26. UNFPA. Maternal Mortality Reduction Programme in Rwanda. Republic of Rwanda; 2012.

27. Yadamsuren B, Merialdi M, Davaadorj I, Requejo JH, Betrán AP, Ahmad A, et al. Tracking maternal mortality declines in Mongolia between 1992 and 2007: the importance of collaboration. Bull World Health Organ. 2010; 88(3):192-8. http://dx.doi.org/10.2471/ BLT.08.061747

28. Health Policy Council. Achievements, Challenges and Horizons of the Health System of the Islamic Republic of Iran. Volume 1. Tehran: Ministry of Health and Medical Education; 2015.

29. World Health Organization. WHO Country Cooperation Strategy. Bhutan. Geneva: World Health Organization; 2014. pp. 2014-8.

30. World Health Organization. Monitoring the building blocks of health systems: a handbook of indicators and their measurement strategies. Geneva: World Health Organization; 2010.

31. Shiffman J. Generating political priority for maternal mortality reduction in 5 developing countries. Am J Public Health. 2007; 97(5):796-803. http://dx.doi.org/10.2105/AJPH.2006.095455

32. Muldoon KA, Galway LP, Nakajima M, Kanters S, Hogg RS, Bendavid E, et al. Health system determinants of infant, child and maternal mortality: A cross-sectional study of UN member countries. Global Health. 2011; 7(1):42. http://dx.doi.org/10.1186/17448603-7-42.

33. Simkhada B, Van Teijlingen E, Porter M, Simkhada P. Major problems and key issues in Maternal Health in Nepal. Kathmandu University Medical Journal. 2006;4(2 (Iss):258-63.

34. Frost L, Pratt B. Review of the literature on factors contributing to the reductions of maternal and child mortality in low income and middle income countries: an evidence synthesis for the success factors study [Partnership for Maternal, New born \& Child Health Technical Paper]. Geneva: World Health Organization; 2014. Global Health Insights. 2014.

35. Shiffman J, Okonofua F. The state of political priority for safe motherhood in Nigeria. BJOG. 2007; 114(2):127-33. http://dx.doi org/10.1111/j.1471-0528.2006.01184.X

36. Mishra C, Thomas J, Kumar R, Basavaraj T, James A, Mohan A, et al. National leadership: driving forward the updated Global Strategy for Women's, Children's and Adolescents' Health. bmj. 2015; 351:h4282.

37. Nguyen MP, Mirzoev T, Le TM. Contribution of health workforce to health outcomes: empirical evidence from Vietnam. Hum Resour Health. 2016; 14(1):68. http://dx.doi.org/10.1186/s12960-016-0165-0

38. Campbell J, Sochas L, Cometto G, Matthews Z. Evidence for action on improving the maternal and newborn health workforce: the basis for quality care. Int J Gynaecol Obstet. 2016;132(1):126-9.

39. Fournier P, Dumont A, Tourigny C, Dunkley G, Dramé S. Improved access to comprehensive emergency obstetric care and its effect on institutional maternal mortality in rural Mali. Bull World Health Organ. 2009;87(1):30-8. http://dx.doi.org/10.2471/ BLT.07.047076 